\title{
EFFECT OF $\mathrm{MgAl}_{2} \mathrm{O}_{4}$ ON THE GROWTH OF $\beta-\mathrm{Si}_{3} \mathrm{Al}_{3} \mathrm{O}_{3} \mathrm{~N}_{5}$ PREPARED BY CARBOTHERMAL REDUCTION BY NITRIDING
}

\author{
ALFREDO FLORES VALDES*, JOSE ALMANZA ROBLES*, JESUS TORRES TORRES*, \\ "ROCIO OCHOA PALACIOS**, JOSE ESCOBEDO BOCARDO*, DORA CORTES HERNANDEZ*, \\ HECTOR HERNANDEZ GARCIA*** \\ *Centro de Investigación y de Estudios Avanzados del IPN, Unidad Saltillo, Ave. Industria Metalúrgica 1062, \\ Parque Industrial Saltillo-Ramos Arizpe, 25900 Ramos Arizpe, Coahuila México \\ **Tecnológico Nacional de México / I.T. Saltillo, Blvd. Venustiano Carranza, Saltillo, Coahuila, 25000 México \\ ***Corporación Mexicana de Investigación en Materiales, Calle Ciencia y Tecnología No. 790, Fracc. Saltillo 400, \\ Saltillo, Coah., 25290 México \\ "E-mail: rochoa@itsaltillo.edu.mx
}

Submitted December 20, 2019; accepted January 20, 2020

Keywords: $\beta-\mathrm{Si}_{3} \mathrm{Al}_{3} \mathrm{O}_{3} \mathrm{~N}_{5}$, Aluminum dross, Ceramic materials, Carbothermic reduction

The $\beta-\mathrm{Si}_{3} \mathrm{Al}_{3} \mathrm{O}_{3} \mathrm{~N}_{5}$ compound was experimentally prepared by carbothermal reduction by nitriding using pure $\mathrm{SiO}_{2}$, $\mathrm{Al}_{2} \mathrm{O}_{3}, \mathrm{C}$, and $\mathrm{N2}$. The effect of $\mathrm{MgAl}_{2} \mathrm{O}_{4}$ on the growth of $\beta-\mathrm{Si}_{3} \mathrm{Al}_{3} \mathrm{O}_{3} \mathrm{~N}_{5}$ was investigated as a function of temperature and molar concentration of $\mathrm{MgAl}_{2} \mathrm{O}_{4}$. In this way, it was found that the formation of $\beta-\mathrm{Si}_{3} \mathrm{Al}_{3} \mathrm{O}_{3} \mathrm{~N}_{5}$ when $\mathrm{MgAl}_{2} \mathrm{O}_{4}$ is present in concentrations lower than $13 \mathrm{wt}$. \% occurs. However, when the $\mathrm{MgAl}_{2} \mathrm{O}_{4}$ concentration was as high as $25.6 \mathrm{wt}$. \%, the formation of $\beta-\mathrm{Si}_{3} \mathrm{Al}_{3} \mathrm{O}_{3} \mathrm{~N}_{5}$ compound was not attained and the formation of quaternary magnesium-rich SiAlON phases such as $\mathrm{Mg}_{-} \mathrm{Si}_{4} \mathrm{Al}_{2} \mathrm{O}_{6} \mathrm{~N}_{4}$ was found. Moreover, the mechanistic steps during the consolidation of SiAlON type structures are presented and discussed.

\section{INTRODUCTION}

It is well known that a significant amount of aluminum alloys for the automotive industry is supplied with secondary smelting aluminum, due to the convenience of using aluminum scrap. However, the aluminum dross that is generated during aluminum recycling can cause pollution problems, due to the diversity of compounds that can be found in its composition [1]. The suitability of preparing high value ceramic compounds such as AIN or $\beta$-SiAlON starting from pollutant materials such as dross produced from secondary smelting aluminum alloys has been broadly discussed [2-8], as this is important from technical, economic and ecological points of view.

On the other hand, the properties of $\beta$-SiAlON type compounds have been extensively studied, these types of ceramics posse excellent mechanical properties at high temperature $\left(\geq 1200{ }^{\circ} \mathrm{C}\right.$ ), having found industrial applications that require high temperature stability, high wear resistance and high fracture toughness [9, 10]. Moreover, their suitability has been tested for using it as a refractory lining of iron blast furnaces [11].

Previous works have presented the preparation of $\beta$-SiAlON type ceramics starting from recycled materials or industrial wastes [8-15]. However, the synthesis of $\beta$-SiAlON type compounds using aluminum dross is a challenge because dross produced in secondary aluminum smelting units such as reverberatory furnaces, the final chemical composition could be quite heterogeneous $[16,17]$. Taking into account possible contamination of materials that can be prepared from aluminum dross containing impurities such as the so-called spinel, with the general formula $\mathrm{MgAl}_{2} \mathrm{O}_{4}$, in this paper it is described the findings of an investigation aimed at obtaining particles of $\beta-\mathrm{Si}_{3} \mathrm{Al}_{3} \mathrm{O}_{3} \mathrm{~N}_{5}$ in the presence of such a compound, starting from pure substances. Therefore, the role of pure $\mathrm{MgAl}_{2} \mathrm{O}_{4}$ on the growth of $\beta-\mathrm{Si}_{3} \mathrm{Al}_{3} \mathrm{O}_{3} \mathrm{~N}_{5}$ using carbothermal reduction by nitriding is presented and discussed.

\section{EXPERIMENTAL}

Preparation of $\beta-\mathrm{Si}_{3} \mathrm{Al}_{3} \mathrm{O}_{3} \mathrm{~N}_{5}$ by carbothermal reduction

The synthesis of $\beta-\mathrm{Si}_{3} \mathrm{Al}_{3} \mathrm{O}_{3} \mathrm{~N}_{5}$ can be done starting from pure $\mathrm{SiO}_{2}$, and $\mathrm{Al}_{2} \mathrm{O}_{3}$ at temperatures above $1400{ }^{\circ} \mathrm{C}$ by carbothermal reduction by nitriding [18-21]. Therefore, the following reaction can be proposed for the synthesis of $\beta-\mathrm{Si}_{3} \mathrm{Al}_{3} \mathrm{O}_{3} \mathrm{~N}_{5}$ under a nitrogen atmosphere:

$$
\begin{aligned}
& 3 \mathrm{SiO}_{2(s)}+1.5 \mathrm{Al}_{2} \mathrm{O}_{3(s)}+7.5 \mathrm{C}_{(s)}+2.5 \mathrm{~N}_{2(g)} \rightarrow \\
& \rightarrow \beta-\mathrm{Si}_{3} \mathrm{Al}_{3} \mathrm{O}_{3} \mathrm{~N}_{5(s)}+7.5 \mathrm{CO}_{(g)}
\end{aligned}
$$

This reaction is spontaneous at temperatures between 1400 and $1700{ }^{\circ} \mathrm{C}$, with a value of $\Delta G^{0}=$ $=-108.10 \mathrm{~kJ} \cdot \mathrm{mol}^{-1}$ at $1500{ }^{\circ} \mathrm{C}$. For optimization of the 
selected parameters during the synthesis of $\beta-\mathrm{Si}_{3} \mathrm{Al}_{3} \mathrm{O}_{3} \mathrm{~N}_{5}$ processing, the experimental conditions will be described below.

The pure compounds used in the synthesis of $\beta-\mathrm{Si}_{3} \mathrm{Al}_{3} \mathrm{O}_{3} \mathrm{~N}_{5}$ were purchased with similar particle sizes: $\mathrm{SiO}_{2}$ (quartz) (99.5 wt. \%, Aldrich, $35 \mu \mathrm{m}$ ), $\mathrm{Al}_{2} \mathrm{O}_{3(\alpha)}$ (high-ultra purity from Sasol, $30 \mu \mathrm{m}), \mathrm{MgO}(99.9 \%$ Aldrich, $35 \mu \mathrm{m}$ ) and $\mathrm{C}\left(\right.$ graphite), $35 \mu \mathrm{m}$. $\mathrm{MgAl}_{2} \mathrm{O}_{4}$ particles were not purchased from local suppliers, instead it was prepared according to the procedure given below.

The following amounts of the main components were weighed: $138 \mathrm{~g}$ of $\mathrm{SiO}_{2 \text { (quartz) }}(3 \mathrm{~mol}), 50 \mathrm{~g}$ of $\mathrm{Al}_{2} \mathrm{O}_{3(\alpha)}(1.5 \mathrm{~mol})$ and $100 \mathrm{~g}$ of $\mathrm{C}_{(\text {graphite })}(7.5 \mathrm{~mol})$. All the pure compounds were homogenized with acetone and then dried at $80{ }^{\circ} \mathrm{C}$ for $12 \mathrm{~h}$. Subsequently, discs of $10 \mathrm{~g}$ each of the dried powder were compacted under uniaxial pressing at $20 \mathrm{MPa}$ and synthesized in a tight closed tubular furnace in the range of temperatures from 1400 to $1600{ }^{\circ} \mathrm{C}$ for $5 \mathrm{~h}$. As carrier and reactive gas, ultra-high pure nitrogen $\left(\mathrm{N}_{2(g)}\right)$ was used at a flow rate of $21 \cdot \mathrm{min}^{-1}$. Considering that the system is open, the $\mathrm{N}_{2}$ pressure was $1 \mathrm{~atm}$. During the synthesis, the $\mathrm{N}_{2(g)}$ flow was preheated at $1200{ }^{\circ} \mathrm{C}$ in a second tubular furnace. It is worth mentioning that the amount of $\mathrm{N}_{2}$ fed to the system ( $28 \mathrm{~g}$, equivalent to 2.5 moles) was not strictly balanced according to the reaction given by reaction (1), as an excess of $300 \% \mathrm{~N}_{2}$ was used in each experiment.

After the reactions, the obtained products were milled and were examined by X-ray diffraction (XRD). The quantitative determinations were done using Rietveld analysis implemented in the Traces Software package of this equipment. Scanning electron microscopy (SEM) observations and semi-quantitative concentration measurements were also performed by energy-dispersive X-ray spectroscopy (EDX) analysis. It is worth mentioning that some samples where it was found the highest amount of $\beta-\mathrm{Si}_{3} \mathrm{Al}_{3} \mathrm{O}_{3} \mathrm{~N}_{5}$ were specially prepared for observations in the SEM using an excitation voltage as low as $1.5 \mathrm{keV}$, to perform EDS analysis of particles accurately. Nevertheless, morphological comparisons of phases with reported analysis of other authors were taken into the account, for assessing stoichiometry of the phases present in the microstructures analyzed in this work.

\section{Preparation of $\mathrm{MgAl}_{2} \mathrm{O}_{4}$}

$\mathrm{MgAl}_{2} \mathrm{O}_{4}$ powders were prepared using high purity $\mathrm{MgO}$ and $\mathrm{Al}_{2} \mathrm{O}_{3}$ particles. The amount used for synthesis was $80 \mathrm{~g}$ of $\mathrm{MgO}$ and $88 \mathrm{~g} \mathrm{Al}_{2} \mathrm{O}_{3}$, with average particles size of $35 \mu \mathrm{m}$ each. Before sintering, the powders were homogenized for $24 \mathrm{~h}$ with acetone. Subsequently, the powders were dried in a furnace at $120^{\circ} \mathrm{C}$ for $12 \mathrm{~h}$. The dried powders were compacted under uniaxial pressing at $200 \mathrm{MPa}$ for $1 \mathrm{~min}$. The sintering of $\mathrm{MgAl}_{2} \mathrm{O}_{4}$ was carried out at $1600{ }^{\circ} \mathrm{C}$ for $6 \mathrm{~h}$ using a heating/cooling rate of $2{ }^{\circ} \mathrm{C} \cdot \mathrm{min}^{-1}$. Finally, the sintered product obtained was milled in a planetary mill and sieved to -325 mesh. Characterization of the reaction product obtained was performed by X-ray diffraction as was described above in section 2.1.

$$
\begin{gathered}
\text { Preparation of } \beta-\mathrm{Si}_{3} \mathrm{Al}_{3} \mathrm{O}_{3} \mathrm{~N}_{5} \\
\text { with } \mathrm{MgAl}_{2} \mathrm{O}_{4}
\end{gathered}
$$

The chemical composition of typical recycled aluminum has been reported extensively $[1,18]$. The main aluminum sources are $\mathrm{AlN}, \mathrm{Al}_{2} \mathrm{O}_{3}$ and $\mathrm{MgAl}_{2} \mathrm{O}_{4}$, with a wide variation in the $\mathrm{MgAl}_{2} \mathrm{O}$ content, depending on the origin of the aluminum source. Taking into the account the molar quantities given by Equation 1, preparation of $\beta-\mathrm{Si}_{3} \mathrm{Al}_{3} \mathrm{O}_{3} \mathrm{~N}_{5}$ was done by varying the content of $\mathrm{MgAl}_{2} \mathrm{O}_{4}$ in the reaction, considering constant the ratio $\mathrm{SiO}_{2} / \mathrm{Al}_{2} \mathrm{O}_{3}$ equal 2, as well as of the $\mathrm{C}$ concentration, as follows:

- with high $\mathrm{MgAl}_{2} \mathrm{O}_{4}$ content (25.6 wt. \%);

- a medium $\mathrm{MgAl}_{2} \mathrm{O}_{4}$ concentration (12.8 wt. \%);

- a low $\mathrm{MgAl}_{2} \mathrm{O}_{4}$ concentration (5.0 wt. \%).

Reference samples were also prepared with no addition of $\mathrm{MgAl}_{2} \mathrm{O}_{4}$.

The syntheses were carried out at the temperatures of 1400 and $1600{ }^{\circ} \mathrm{C}$ for $5 \mathrm{~h}$. The chemical compounds used were according to the amounts indicated in Table 1. The results of experimental procedure were determined using X-ray diffraction and SEM analysis using EDS.

\section{RESULTS AND DISCUSSION}

\section{Preparation of $\beta-\mathrm{Si}_{3} \mathrm{Al}_{3} \mathrm{O}_{3} \mathrm{~N}_{5}$} by carbothermal reduction

Figure 1a shows the XRD pattern of a sample of reaction products obtained at $1600{ }^{\circ} \mathrm{C}$, after 5 hours of reaction. This pattern indicates the diffraction lines of the hexagonal structure of the $\beta-\mathrm{Si}_{3} \mathrm{Al}_{3} \mathrm{O}_{3} \mathrm{~N}_{5}$ phase (ICDD card number 01-079-0483) [18-20]. SEM micrograph confirms in Figure $1 \mathrm{~b}$, the appearance of the single $\beta-\mathrm{Si}_{3} \mathrm{Al}_{3} \mathrm{O}_{3} \mathrm{~N}_{5}$ phase, indicating that it can be successfully synthesized at these conditions. SEM micrograph of Figure 2, corresponding to specially prepared sample observed at the lowest excitation voltage in the SEM $(1.5 \mathrm{keV})$, showing elongated particles similar to fibers, with no uniform shape, corresponding to the $\beta-\mathrm{Si}_{3} \mathrm{Al}_{3} \mathrm{O}_{3} \mathrm{~N}_{5}$ phase. By X-ray diffraction analysis the largest number of crystalline phases that can be detected must be greater than $5 \mathrm{wt}$. $\%$, so it is possible to state that under the experimental conditions stated above, a minimum of $95 \%$ of the original materials were transformed into the $\beta-\mathrm{Si}_{3} \mathrm{Al}_{3} \mathrm{O}_{3} \mathrm{~N}_{5}$ phase. The formation mechanism of $\beta-\mathrm{Si}_{3} \mathrm{Al}_{3} \mathrm{O}_{3} \mathrm{~N}_{5}$ is quite complex, so in the literature many mechanisms have been suggested, which depend on the concentrations of the starting materials [22-25]. 


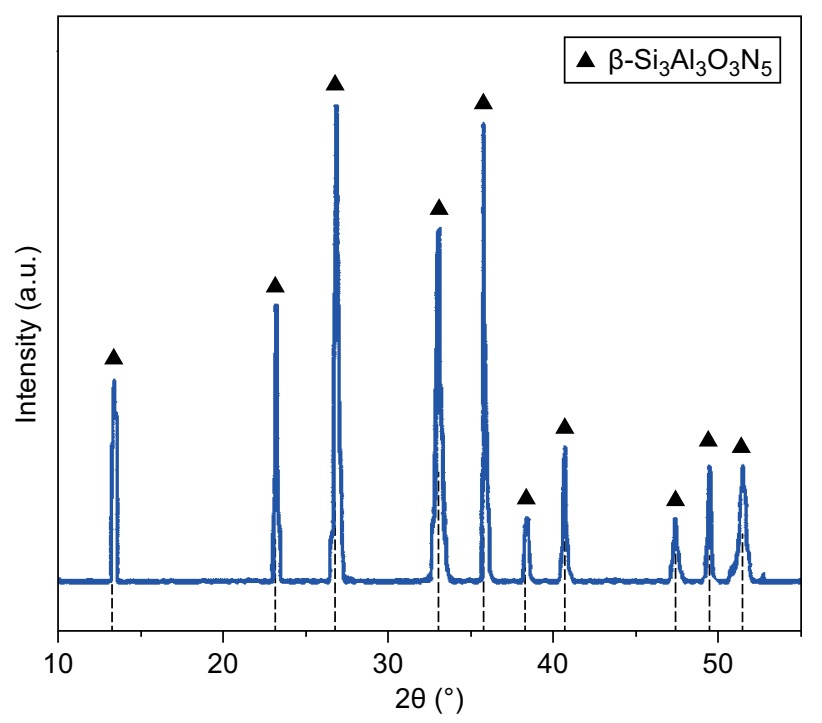

a)

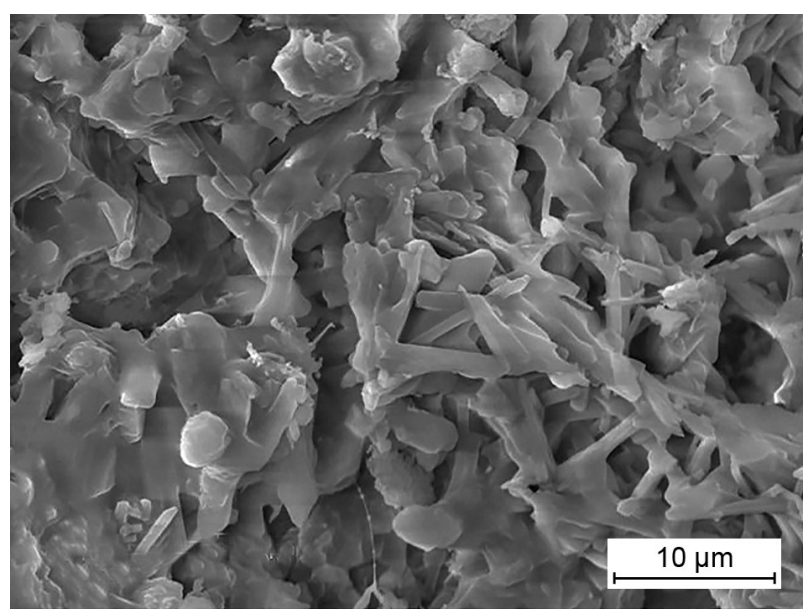

b)

Figure 1. a) X-ray diffraction pattern of the reaction products obtained after 5 hours at $1600{ }^{\circ} \mathrm{C}$; b) SEM micrograph of the reaction products, where the microstructure corresponds mainly to the $\beta-\mathrm{Si}_{3} \mathrm{Al}_{3} \mathrm{O}_{3} \mathrm{~N}_{5}$ phase (ICDD card number 01-0790483) [18-20].

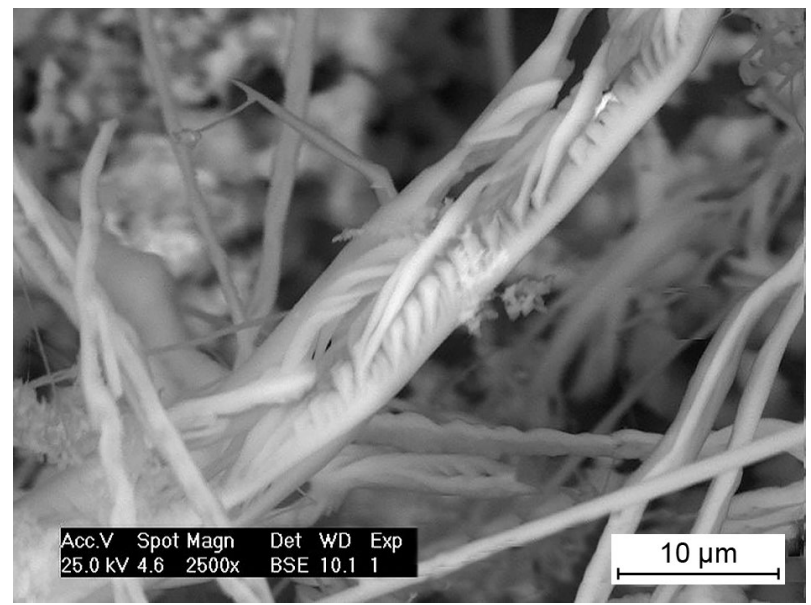

Figure 2. SEM micrograph of a sample processed at $1600^{\circ} \mathrm{C}$ for $5 \mathrm{~h}$, where the fibers of the $\beta-\mathrm{Si}_{3} \mathrm{Al}_{3} \mathrm{O}_{3} \mathrm{~N}_{5}$ are seen.
If the sources of aluminum and silicon are their oxides, it has been reported that $\mathrm{SiO}_{2}$ and $\mathrm{Al}_{2} \mathrm{O}_{3}$ can be reduced with graphite in the presence of nitrogen. During the reactions taking place, the $\mathrm{SiO}_{(g)}$ species could be formed, and subsequently $\mathrm{AlO}_{(g)}$ and $\mathrm{Si}_{3} \mathrm{~N}_{4}$ are also formed. After some additional steps, the formation of $\beta-\mathrm{Si}_{3} \mathrm{Al}_{3} \mathrm{O}_{3} \mathrm{~N}_{5}$ takes place. It is well known that $\beta$-SiAlON type phases are solid solutions of $\beta-\mathrm{Si}_{3} \mathrm{~N}_{4}, \mathrm{Al}_{2} \mathrm{O}_{3}$ and $\mathrm{AlN}$, these present the general formula $\mathrm{Si}_{6-z} \mathrm{Al}_{z} \mathrm{O}_{z} \mathrm{~N}_{8-z}$, where $z=0-4.3[10,15] . \beta-\mathrm{Si}_{3} \mathrm{~N}_{4}$ and $\beta-\mathrm{Si}_{3} \mathrm{Al}_{3} \mathrm{O}_{3} \mathrm{~N}_{5}$ phases present a hexagonal structure. Lattice constants of this phase increases as the concentration of $\mathrm{Al}$ increases. The growth mechanism of the elongated $\beta-\mathrm{Si}_{3} \mathrm{Al}_{3} \mathrm{O}_{3} \mathrm{~N}_{5}$ particles can be explained considering the formation of gaseous species such as $\mathrm{SiO}_{(g)}$ and $\mathrm{Al}_{2} \mathrm{O}_{(g)}$. The following reactions summarize the growth mechanism $[19,26]$ :

$$
\begin{gathered}
\mathrm{SiO}_{2(s)}+\mathrm{C}_{(\text {graphite) }}=\mathrm{SiO}_{(g)}+\mathrm{CO}_{(g)} \\
\mathrm{Al}_{2} \mathrm{O}_{3(g)}+2 \mathrm{C}_{\text {(graphite) }}=\mathrm{Al}_{2} \mathrm{O}_{(g)}+\mathrm{CO}_{(g)}
\end{gathered}
$$

Subsequently, $\mathrm{SiO}_{(g)}$ species may form $\mathrm{Si}_{3} \mathrm{~N}_{4}$ initial seeds. Where $\mathrm{Si}_{3} \mathrm{~N}_{4}$ can be formed through the following reaction:

$$
\begin{gathered}
3 \mathrm{SiO}_{(g)}+3 \mathrm{C}_{(\text {graphite })}+2 \mathrm{~N}_{2(g)}=\mathrm{Si}_{3} \mathrm{~N}_{4(g)}+3 \mathrm{CO}_{(g)} \\
\Delta G^{\mathrm{o}}{ }_{1400^{\circ} \mathrm{C}}=-251.7 \mathrm{~kJ} ; \Delta G^{\mathrm{o}}{ }_{1600^{\circ} \mathrm{C}}=-181.9 \mathrm{~kJ} .
\end{gathered}
$$

Vapors of $\mathrm{SiO}_{(g)}$ and $\mathrm{Al}_{2} \mathrm{O}_{(g)}$ react with $\mathrm{N}_{2(g)}$ and are deposited on a preferential crystal direction of $\beta-\mathrm{Si}_{3} \mathrm{~N}_{4}$ seeds, in a further step the $\beta-\mathrm{Si}_{3} \mathrm{Al}_{3} \mathrm{O}_{3} \mathrm{~N}_{5}$ elongated particles are generated. This mechanism of reaction has been broadly discussed in literature [27-30] and it is accepted in this work, mainly for the limitations in analyzing the gaseous species generated during our experiments.

The role of $\mathrm{MgAl}_{2} \mathrm{O}_{4}$ on the preparation of $\beta-\mathrm{Si}_{3} \mathrm{Al}_{3} \mathrm{O}_{3} \mathrm{~N}_{5}$

To study the effect of $\mathrm{MgAl}_{2} \mathrm{O}_{4}$ on the $\beta-\mathrm{Si}_{3} \mathrm{Al}_{3} \mathrm{O}_{3} \mathrm{~N}_{5}$ growth, this material was prepared and characterized. Figure 3 shows the XRD pattern of the obtained powder, where, as it can be seen, under the experimental conditions mentioned in section 2.3, the $\mathrm{MgA}_{2} \mathrm{O}_{4}$ (spinel, ICDD card number 00-021-1152) was successfully obtained. Table 1 shows the quantitative results of X-ray diffraction for the experimental conditions studied in this work, as the $\beta-\mathrm{Si}_{3} \mathrm{Al}_{3} \mathrm{O}_{3} \mathrm{~N}_{5}$ solid solution could be formed with different $\mathrm{MgAl}_{2} \mathrm{O}_{4}$ concentrations only at the two temperatures $\left(1400\right.$ and $\left.1600{ }^{\circ} \mathrm{C}\right)$, also presents others reaction products obtained of the different phases mixtures. It is important to note that when the $\mathrm{MgAl}_{2} \mathrm{O}_{4}$ concentration is the highest (sample A), the $\beta-\mathrm{Si}_{3} \mathrm{Al}_{3} \mathrm{O}_{3} \mathrm{~N}_{5}$ phase is obtained in a maximum quantity of $25.52 \mathrm{wt}$. \% at $1600{ }^{\circ} \mathrm{C}$. Nevertheless, when $\mathrm{MgAl}_{2} \mathrm{O}_{4}$ is present in low or medium concentrations (5 or $12.8 \mathrm{wt} \%$ ), a low yield of $\beta-\mathrm{Si}_{3} \mathrm{Al}_{3} \mathrm{O}_{3} \mathrm{~N}_{5}$ is obtained at $1400{ }^{\circ} \mathrm{C}$. Otherwise, 
when the reaction was carried out at $1600{ }^{\circ} \mathrm{C}$, the $\beta-\mathrm{Si}_{3} \mathrm{Al}_{3} \mathrm{O}_{3} \mathrm{~N}_{5}$ was obtained in higher percentages $(42.96$ and 65.71 wt. \%, respectively). For reactions $\mathrm{C}(5 \mathrm{wt} . \%$ $\mathrm{MgAl}_{2} \mathrm{O}_{4}$ ) at $1600{ }^{\circ} \mathrm{C}, 65.71$ wt. $\%$ of $\beta-\mathrm{Si}_{3} \mathrm{Al}_{3} \mathrm{O}_{3} \mathrm{~N}_{5}$ was obtained. Obviously, when $\mathrm{MgAl}_{2} \mathrm{O}_{4}$ is not added during preparation of $\beta-\mathrm{Si}_{3} \mathrm{Al}_{3} \mathrm{O}_{3} \mathrm{~N}_{5}$, the percentage of this compound was the highest.

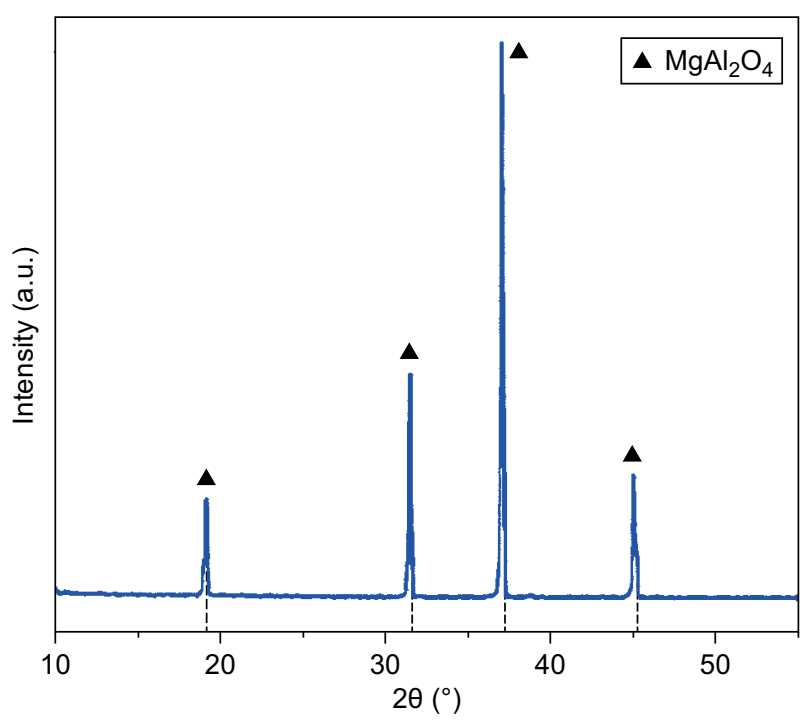

Figure 3. X-Ray diffraction pattern of the synthesized $\mathrm{MgAl}_{2} \mathrm{O}_{4}$ compound.
Figure 4 shows a SEM micrograph of sample C obtained at $1600{ }^{\circ} \mathrm{C}$, after 5 hours of reaction, using the lowest voltage excitation in the SEM $(1.5 \mathrm{keV})$. In the background, massive particles with irregular morphology (labeled a in the micrograph) can be appreciated, which correspond to the $\beta-\mathrm{Si}_{3} \mathrm{Al}_{3} \mathrm{O}_{3} \mathrm{~N}_{5}$ phase. Additionally, ribbon-like morphology particles (labeled $\mathrm{b}$ in the micrograph) $\sim 1.5 \mu \mathrm{m}$ wide and $\sim 15 \mu \mathrm{m}$ length can be observed. SEM analysis of the rods by EDS suggested that these are $\mathrm{Mg}-\mathrm{Si}_{4} \mathrm{Al}_{2} \mathrm{O}_{6} \mathrm{~N}_{4}$ particles. In order to explain the role of $\mathrm{MgAl}_{2} \mathrm{O}_{4}$ on the growth of $\beta-\mathrm{Si}_{3} \mathrm{Al}_{3} \mathrm{O}_{3} \mathrm{~N}_{5}$, the process of densification and phase transformations will be described. Terms for this process are frequently known as Transient LiquidPhase (TLP) and sintering. For the formation of $\mathrm{Si}_{3} \mathrm{~N}_{4}$ and $\beta-\mathrm{Si}_{3} \mathrm{Al}_{3} \mathrm{O}_{3} \mathrm{~N}_{5}$ ceramics, it has been reported that the presence of $\mathrm{Mg}$ promotes the formation of the TLP and activates the densification process [31]. Similar effects can be observed in the samples prepared with low and medium content of $\mathrm{MgAl}_{2} \mathrm{O}_{4}$, where at temperatures as low as $1400{ }^{\circ} \mathrm{C}, \beta-\mathrm{Si}_{3} \mathrm{Al}_{3} \mathrm{O}_{3} \mathrm{~N}_{5}$ was incipiently formed, as it can be seen in Table 1, samples C. Here it can be concluded that $\mathrm{MgAl}_{2} \mathrm{O}_{4}$ does not inhibit the formation of $\beta-\mathrm{Si}_{3} \mathrm{Al}_{3} \mathrm{O}_{3} \mathrm{~N}_{5}$ at low concentrations.

The growth of the ribbon-like particles shown in Figure $4 \mathrm{~b}$ can be related to vapor-solid (VS) and vaporliquid-solid (VLS) growth mechanisms. As the formation of TLP is promoted at the higher contents of $\mathrm{MgAl}_{2} \mathrm{O}_{4}$

Table 1. Crystalline phases detected by X-ray diffraction and error deviation of phase percent calculated of synthesized samples with and without $\mathrm{MgAl}_{2} \mathrm{O}_{4}$ at 1400 and $1600{ }^{\circ} \mathrm{C}$ for $5 \mathrm{~h}$ under $\mathrm{N}_{2}$ flow.

\begin{tabular}{|c|c|c|c|c|c|c|c|}
\hline Sample & $\begin{array}{l}\mathrm{MgAl}_{2} \mathrm{O}_{4} \\
\text { (wt. \%) }\end{array}$ & $\begin{array}{l}\text { Crystalline phases } \\
\left(1400^{\circ} \mathrm{C}\right)\end{array}$ & $\begin{array}{l}\text { Phase } \\
(\%)\end{array}$ & $\begin{array}{l}\text { Std. Dev } \\
\qquad( \pm)\end{array}$ & $\begin{array}{c}\text { Crystalline phases } \\
\left(1600^{\circ} \mathrm{C}\right)\end{array}$ & $\begin{array}{l}\text { Phase } \\
(\%)\end{array}$ & $\begin{array}{l}\text { Std. Dev. } \\
\qquad( \pm)\end{array}$ \\
\hline \multirow{7}{*}{ A } & \multirow{7}{*}{25.64} & $\alpha-\mathrm{Al}_{2} \mathrm{O}_{3}$ & 34.44 & 0.62 & $\beta-\mathrm{Si}_{3} \mathrm{Al}_{3} \mathrm{O}_{3} \mathrm{~N}_{5}$ & 25.52 & 0.15 \\
\hline & & AlN & 32.54 & 0.55 & AlN & 19.51 & 0.38 \\
\hline & & $\beta-\mathrm{Si}_{2} \mathrm{Al}_{4} \mathrm{O}_{4} \mathrm{~N}_{4}$ & 9.97 & 0.45 & $\beta-\mathrm{Si}_{2} \mathrm{Al}_{4} \mathrm{O}_{4} \mathrm{~N}_{4}$ & 16.47 & 0.27 \\
\hline & & $\mathrm{MgAl}_{2} \mathrm{O}_{4}$ & 5.81 & 1.02 & $\mathrm{MgAl}_{2} \mathrm{O}_{4}$ & 13.52 & 0.85 \\
\hline & & $\mathrm{MgSiN}_{2}$ & 6.23 & 0.27 & $\mathrm{MgSiN}_{2}$ & 9.28 & 1.00 \\
\hline & & $\mathrm{Mg}-\mathrm{Si}_{4} \mathrm{Al}_{2} \mathrm{O}_{6} \mathrm{~N}_{4}$ & 11.01 & 0.56 & $\mathrm{Mg}-\mathrm{Si}_{4} \mathrm{Al}_{2} \mathrm{O}_{6} \mathrm{~N}_{4}$ & 15.70 & 0.66 \\
\hline & & TOTAL & 100 & & TOTAL & 100 & \\
\hline \multirow{7}{*}{ B } & \multirow{7}{*}{12.82} & $\alpha-\mathrm{Al}_{2} \mathrm{O}_{3}$ & 46.28 & 0.23 & $\beta-\mathrm{Si}_{3} \mathrm{Al}_{3} \mathrm{O}_{3} \mathrm{~N}_{5}$ & 42.96 & 0.11 \\
\hline & & AlN & 23.21 & 0.42 & AlN & 17.53 & 0.15 \\
\hline & & $\beta-\mathrm{Si}_{2} \mathrm{Al}_{4} \mathrm{O}_{4} \mathrm{~N}_{4}$ & 10.63 & 0.48 & $\mathrm{Si}_{3} \mathrm{~N}_{4}$ & 6.89 & 0.65 \\
\hline & & $\mathrm{MgAl}_{2} \mathrm{O}_{4}$ & 5.05 & 0.95 & $\mathrm{MgSiN}_{2}$ & 5.28 & 0.74 \\
\hline & & $\mathrm{MgSiN}_{2}$ & 7.12 & 1.10 & $\mathrm{Mg}-\mathrm{Si}_{4} \mathrm{Al}_{2} \mathrm{O}_{6} \mathrm{~N}_{4}$ & 27.34 & 0.67 \\
\hline & & $\mathrm{Mg}-\mathrm{Si}_{4} \mathrm{Al}_{2} \mathrm{O}_{6} \mathrm{~N}_{4}$ & 7.71 & 0.33 & & & \\
\hline & & TOTAL & 100 & & TOTAL & 100 & \\
\hline \multirow{6}{*}{$\mathrm{C}$} & \multirow{6}{*}{5.00} & AlN & 32.02 & 0.11 & $\beta-\mathrm{Si}_{3} \mathrm{Al}_{3} \mathrm{O}_{3} \mathrm{~N}_{5}$ & 65.71 & 0.23 \\
\hline & & $\mathrm{Mg}_{0.38} \mathrm{Si}_{22.40} \mathrm{O}_{4}$ & 26.27 & 0.71 & $\mathrm{Mg}-\mathrm{Si}_{4} \mathrm{Al}_{2} \mathrm{O}_{6} \mathrm{~N}_{4}$ & 21.23 & 0.56 \\
\hline & & $\mathrm{MgSiN}_{2}$ & 16.43 & 0.62 & $\mathrm{MgSiN}_{2}$ & 13.06 & 0.54 \\
\hline & & $\beta-\mathrm{Si}_{2} \mathrm{Al}_{4} \mathrm{O}_{4} \mathrm{~N}_{4}$ & 11.09 & 0.59 & & & \\
\hline & & $\beta-\mathrm{Si}_{3} \mathrm{Al}_{3} \mathrm{O}_{3} \mathrm{~N}_{5}$ & 14.19 & 0.72 & & & \\
\hline & & TOTAL & 100 & & TOTAL & 100 & \\
\hline \multirow{3}{*}{$\begin{array}{l}\text { Reference } \\
\text { sample }\end{array}$} & \multirow{3}{*}{0.00} & \multirow{3}{*}{$\begin{array}{l}- \\
-\end{array}$} & \multirow{3}{*}{$\begin{array}{l}- \\
-\end{array}$} & \multirow{3}{*}{$\begin{array}{l}- \\
-\end{array}$} & $\mathrm{Al}_{2} \mathrm{O}_{3}$ & 4.11 & 0.23 \\
\hline & & & & & $\beta-\mathrm{Si}_{3} \mathrm{Al}_{3} \mathrm{O}_{3} \mathrm{~N}_{5}$ & 95.89 & 0.46 \\
\hline & & & & & TOTAL & 100 & \\
\hline
\end{tabular}


during the carbothermal reaction, it can be inferred that a VLS mechanisms is involved during the growth of ribbons. As in the case of preparation of samples A and $\mathrm{B}$ at $1400{ }^{\circ} \mathrm{C}$, the silicon-aluminum oxide melt is formed and then gaseous species of $\mathrm{SiO}, \mathrm{Al}_{2} \mathrm{O}$ and $\mathrm{N}_{2(g)}$ induce the formation of $\mathrm{Mg}-\mathrm{Si}_{4} \mathrm{Al}_{2} \mathrm{O}_{6} \mathrm{~N}_{4}$ over $\beta-\mathrm{Si}_{3} \mathrm{Al}_{3} \mathrm{O}_{3} \mathrm{~N}_{5}$ crystals. This mechanism explains how the ribbon-like particles were formed. It can be stated that ribbons are the nucleus of $\beta-\mathrm{Si}_{3} \mathrm{Al}_{3} \mathrm{O}_{3} \mathrm{~N}_{5}$ particles developed after $5 \mathrm{~h}$ of reaction at $1600^{\circ} \mathrm{C}$, as it can be seen in same Figure 4 .

Figure 5 shows a SEM micrograph of the reaction products prepared at $1400{ }^{\circ} \mathrm{C}$ for $5 \mathrm{~h}$, for the sample A, prepared when using the highest amount of $\mathrm{MgAl}_{2} \mathrm{O}_{4}$ (25.64 wt. \%). Some solidified droplets can be observed. The EDS spectra of typical particles is attached to the figure, as well as that of the substrate corresponding to $\beta-\mathrm{Si}_{3} \mathrm{Al}_{3} \mathrm{O}_{3} \mathrm{~N}_{5}$. From this figure, it can see by EDS that

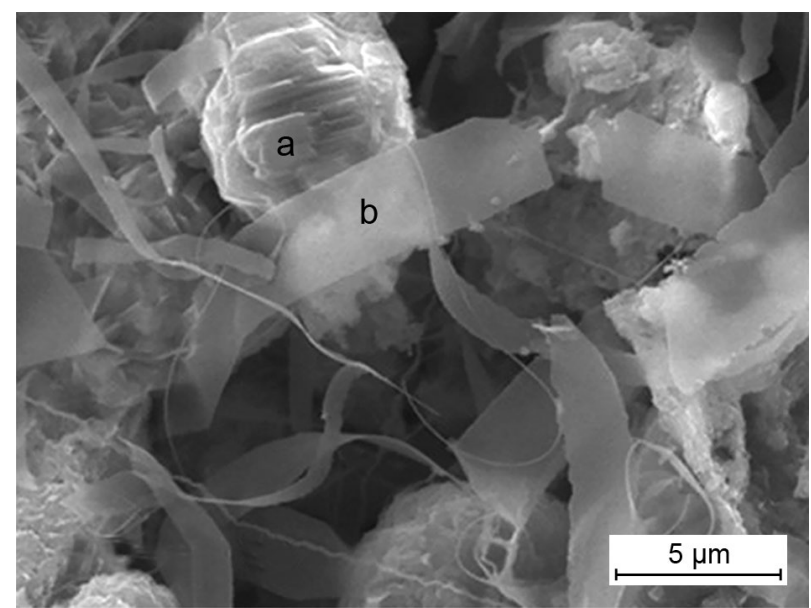

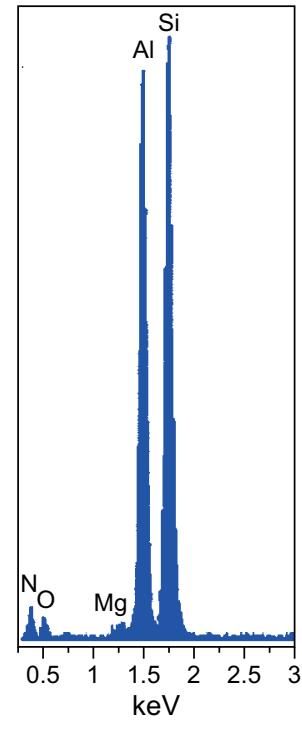

a)

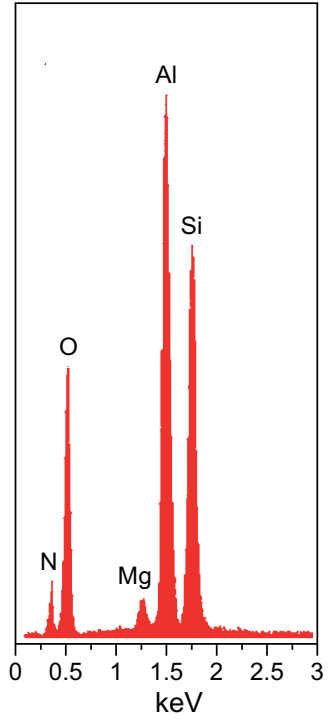

b)
Figure 4. SEM micrograph of sample $\mathrm{C}$ prepared at $1600{ }^{\circ} \mathrm{C}$ after 5 hours of reaction, using a concentration of $\mathrm{MgAl}_{2} \mathrm{O}_{4}$ of 5.0 wt. \%, where the identified compounds by EDS are as follows: a) $\beta-\mathrm{Si}_{3} \mathrm{Al}_{3} \mathrm{O}_{3} \mathrm{~N}_{5}$ and b) $\mathrm{Mg}-\mathrm{Si}_{4} \mathrm{Al}_{2} \mathrm{O}_{6} \mathrm{~N}_{4}$ particles. Their corresponding EDS patterns are attached. the droplets contain $\mathrm{Mg}, \mathrm{Si}, \mathrm{Al}$, and $\mathrm{O}$, by the chemical composition reported it is suggested that these correspond to the $\mathrm{Mg}-\mathrm{Si}_{4} \mathrm{Al}_{2} \mathrm{O}_{6} \mathrm{~N}_{4}$ phase. This phenomenon (generation of droplets) was observed in all the samples prepared at $1400{ }^{\circ} \mathrm{C}$. This effect can be attributed to the fact that $\mathrm{MgAl}_{2} \mathrm{O}_{4}$ promotes the formation of a low melting point silicon-aluminum oxide of unknown origin $[32,33]$, and when it is solidified, it forms this kind of material.

\section{CONCLUSIONS}

The conditions for preparation of $\beta-\mathrm{Si}_{3} \mathrm{Al}_{3} \mathrm{O}_{3} \mathrm{~N}_{5}$ particles were experimentally investigated with and without additions of $\mathrm{MgAl}_{2} \mathrm{O}_{4}$. During a first experimental stage, it was found that at $1600{ }^{\circ} \mathrm{C}$ the $\beta-\mathrm{Si}_{3} \mathrm{Al}_{3} \mathrm{O}_{3} \mathrm{~N}_{5}$ compound can be obtained with a purity

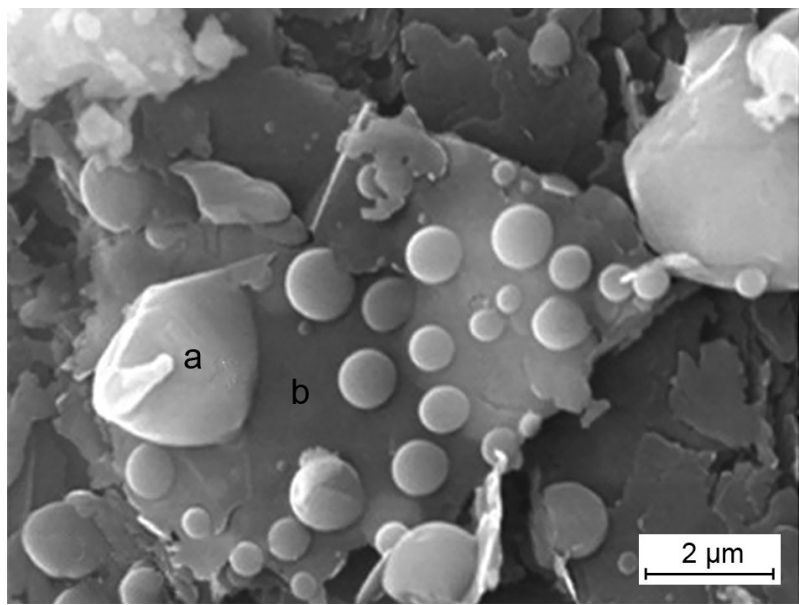

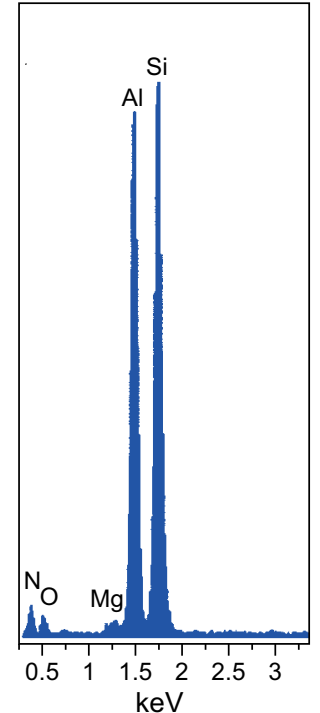

a)

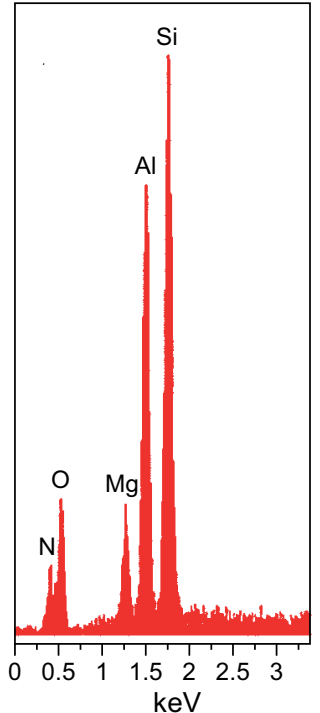

b)

Figure 5. SEM micrograph of a sample prepared at $1400{ }^{\circ} \mathrm{C}$ for $5 \mathrm{~h}$ under $\mathrm{N}_{2}$ flow, using a concentration of $\mathrm{MgAl}_{2} \mathrm{O}_{4}$ of 25.64 wt. \%: a) droplet of a $\mathrm{Mg}_{-} \mathrm{Si}_{4} \mathrm{Al}_{2} \mathrm{O}_{6} \mathrm{~N}_{4}$ phase; b) $\beta$ - $\mathrm{Si}_{3} \mathrm{Al}_{3} \mathrm{O}_{3} \mathrm{~N}_{5}$ substrate. The EDS spectra of both phases are attached. 
of $95 \%$, when no $\mathrm{MgAl}_{2} \mathrm{O}_{4}$ is present. Then, in a second experimental stage, it was found that the presence of $\mathrm{MgAl}_{2} \mathrm{O}_{4}$ during the carbothermal reduction reaction promotes the formation of a transient liquid phase. This encourages the growth of $\beta-\mathrm{Si}_{3} \mathrm{Al}_{3} \mathrm{O}_{3} \mathrm{~N}_{5}$ particles through a vapor-liquid-solid mechanism. However, the $\beta-\mathrm{Si}_{3} \mathrm{Al}_{3} \mathrm{O}_{3} \mathrm{~N}_{5}$ growth is suppressed when the $\mathrm{MgAl}_{2} \mathrm{O}_{4}$ content is too high, which was attributed to the formation of low-melting phases, such as $\mathrm{Mg}-\mathrm{Si}_{4} \mathrm{Al}_{2} \mathrm{O}_{6} \mathrm{~N}_{4}$. It is believed that the ribbon-like morphology of this $\mathrm{Mg}$-rich SiAlON phase could serve as reinforcing particles of the SiAlON phase obtained, therefore this magnesium-rich phase could not be detrimental during preparation of SiAlON type compounds.

\section{REFERENCES}

1. Das B. R., Das B., Tripathy B.C. (2007): Production of $\eta$-alumina from waste aluminium dross. Minerals Engineering, 20, 252-258. doi: 10.1016/j.mineng.2006.09.002

2. Mandal H. (1999): New developments in $\alpha$-sialon ceramics. Journal of the European Ceramic Society, 19, 2349-2357. doi: 10.1016/S0955-2219(99)00111-9

3. Yang Z., Shang Q., Shen X. (2017): Effect of composition on phase assemblage, microstructure, mechanical and optical properties of Mg-doped sialon. Journal of the European Ceramic Society, 37, 91-98. doi: 10.1016/j. jeurceramsoc.2016.08.007

4. Jones M., Hyuga H., Hirao K., (2004): Highly transparent Lu- $\alpha-S i A l O N$. Journal of the American Ceramic Society, 87, 714-716. doi: 10.1111/j.1551-2916.2004.00714.x

5. Shan. Y., Wang G., Sun X. (2015): Improvement of hightemperature oxidation resistance of $\mathrm{Y}$ - $\alpha$-sialon with high nitrogen content by lowering Y/Xi ratio. Journal of Alloys and Compounds, 636, 138-144. doi: 10.1016/j.jallcom. 2015.02.169

6. Yang Z., Wang H., Min X. (2012): Optical and mechanical properties of $\mathrm{Mg}$-doped sialon composite with $\mathrm{La}_{2} \mathrm{O}_{3}$ as additive. Journal of the European Ceramic Society, 32, 931-935. doi: 10.1016/j.jeurceramsoc.2011.10.020

7. Li J., Ma H., Fang Q. (2008): Synthesis of prismatic $\beta$-sialon from the precursor of SBA-15 incorporated with $\mathrm{Al}\left(\mathrm{NO}_{3}\right)_{3}$ via carbothermal reduction nitridation. Ceramics International, 34(2008) 1791-1795. doi: 10.1016/j.ceramint. 2006.04.026

8. Li J., Wang J., Chen H. (2010): Synthesis of $\beta-S i A l O N-A I N-$ Polytypoid ceramics from aluminum dross. Materials Transactions, 15, 844-848. doi: 10.2320/matertrans.MH200913

9. Liu X., Xu E., Zhou C. (2011): Thermo-mechanical properties and microstructure of $\mathrm{Al}_{2} \mathrm{O}_{3}-\mathrm{SiC}-\mathrm{SiAlON}$ composites. Advanced Materials Research, 295-297, 161-164. doi: 10.4028/www.scientific.net/AMR.295-297.161

10. Dobrzański L.A. Staszuk M, Křiž A., Lukaszkowicz K. (2009): Structure and mechanical properties of PVD gradient coatings deposited onto tool steels and sialon tool ceramics. Journal of Achievements in Materials and Manufacturing Engineering, 37, 36-43.

11. Tang Y., Yin H., Ren Y. (2010): Preparation of Sialon powder from coal gasification slag. Journal of Wuhan University of Technology-Mater. Sci. Ed., 6, 1044-1046. doi: 10.1007/s11595-010-0146-4
12. Li P., Zhang M., Wanga Z., Seetharaman S. (2015): BF slag resistance of $\beta-\mathrm{Si}_{3} \mathrm{Al}_{3} \mathrm{O}_{3} \mathrm{~N}_{5}$ material derived from Al salt cake. Journal of the European Ceramic Society, 35, 1307-1315. doi: 10.1016/j.jeurceramsoc.2014.11.002

13. Li P., Zhang M., Teng L., Seetharaman S. (2013): Recycling of Aluminum Salt Cake: Utilization of Evolved Ammonia. Metallurgical and Materials Transactions B, 44, 16-19. doi: 10.1007/s11663-012-9779-3

14. Li P., Zhang M., Teng L., Seetharaman S. (2013): Oxidation Studies of SiAlON/MgAlON Ceramics with $\mathrm{Fe}_{2} \mathrm{O}_{3}$ and $\mathrm{CaO}$ Impurities, Part I: Kinetics. Metallurgical and Materials Transactions B, 44, 210-219. doi: 10.1007/s11663-0129763-y

15. Hotta M., Tatami J., Komeya K. (2010): Effects of starting composition and carbon content on the formation of $\mathrm{Ca}-\alpha$ SiAlON powders by carbothermal reduction-nitridation. Journal of the Ceramic Society of Japan, 118, 827-829. doi: $10.2109 /$ jcersj2.118.827

16. Li J., Wang J., Chen H., Sun B. (2012): Microstructure observation of $\beta$-sialon -15R ceramics synthesized from aluminum dross. Ceramics International, 4, 3075-3080. doi: 10.1016/j.ceramint.2011.12.006

17. Xu X., Liang H., Li X., Wan Y. (2010): In situ synthesis and phase analysis of low density $\mathrm{O}^{\prime}$-sialon-based multiphase ceramics. Rare Metals, 29, 214-219. doi: 10.1007/s12598010-0037-z

18. Ibarra, J. Almanza, Cortes D., Escobedo J., Torres J. (2009): Development of mullite/zirconia composites from a mixture of aluminum dross and zircon. Ceramics International, 35, 921-924. doi:10.1016/j.ceramint.2008.03.006

19. P. Dong, X. Wang, M. Zhang, M. Guo, S. Seetharaman, (2008): The preparation and characterization of $\beta$-sialon nanostructure whiskers Journal of Nanomaterials, 28(2008) 1-6. doi: $10.1155 / 2008 / 282187$

20. Dong P., Wang X., Zhang M., Guo M., Li W. (2009): Thermodynamic study and syntheses of $\beta$-SiAlON ceramics. Sci. China Ser E- Technol. Sci., 52, 3122-31227. doi: 10.1007/s11431-009-0136-y

21. Xu X., Nishimura T., Hirosaki N. (2005): Fabrication of $\beta$-sialon nanoceramics by high-energy mechanical milling and spark plasma sintering. Nanotechnology, 16, 569-573. doi: 10.1088/0957-4484/16/9/027

22. Narciso F.J., Linares A., Rodriguez F. (1995): Synthesis of $\beta$-sialon from coals or natural graphite, Journal of Materials Research, 10, 727-735. doi: 10.1557/JMR.1995.0727

23. Qiu J., Tatami J., Zhang Z., Komeya K., Meguro T., Cheng Y. (2002): Influence of starting material composition and carbon content on the preparation of $\mathrm{Mg}-\alpha-\mathrm{SiAlON}$ powders by carbothermal reduction-nitridation. Journal of the European Ceramic Society, 22, 2989-2996. doi: 10.1016/S0955-2219(02)00055-9

24. Zenotchkine M., Shuba R., Chen I. (2004): Liquid-phase growth of small crystals for seeding $\beta$-sialon ceramics. Journal of the American Ceramic Society,87, 1040-1046. doi: 10.1111/j.1551-2916.2004.01040.x

25. Izhevskiy V., Genova L., Bressiani J., Aldinger F. (2000): Progress in SiAlON ceramics. Journal of the European Ceramic Society, 20, 2275-2295. doi: 10.1016/S0955-2219 (00)00039-X

26. Sopicka M., Terpstra R., Metselaar R. (1995): Carbothermal production of $\beta$-sialon from alumina, silica and carbon mixture. Journal of Materials Science, 30, 6363-6369. doi: 10.1007/BF00369690 
27. He E., Yue J., Fan L., Wang C., Wang H. (2011): Synthesis of single phase $\beta$-SiAlON ceramics by reactionbonded sintering using $\mathrm{Si}$ and $\mathrm{Al}_{2} \mathrm{O}_{3}$ as raw materials. Scripta Materialia, 65 155-158. doi: 10.1016/j.scriptamat. 2011.03.040

28. Xu X, Nishimura T., Hirosaki N., Xie R., Yamamoto Y., Tanaka H. (2005): Fabrication of $\beta$-sialon nanoceramics by high-energy mechanical milling and spark plasma sintering. Nanotechnology, 16, 569-573. doi: 10.1088/0957$4484 / 16 / 9 / 027$

29. Ganesh I. (2011): Development of $\beta$-SiAlON based ceramics for radome applications. Processing and Application of Ceramics, 5, 113-138. doi: 10.2298/PAC1103113G
30. Wang M.J., Wada H. (1989): Silicon nitride whisker synthesis by carbothermal reduction of silica. Materials Science Forum, 47, 267-281. doi: 10.4028/www.scientific. net/MSF.47.267

31. Drew P, Lewis M. (1979): The microstructures of silicon nitride ceramics during hot pressing transformations. Journal of Materials Science, 9, 261-269. doi: 10.1007/ BF00550950

32. Lewis M., Powell B., Drew P. (1977): The formation of single-phase Si-Al-O-N ceramics. Journal of Materials Science, 12, 61-74. doi: 10.1007/BF00738472

33. Lewis M., Bhatti A., Lumby R., North B. (1980): The microstructure of sintered Si-Al-ON ceramics. Journal of Materials Science, 15, 103-113. doi: 10.1007/BF00552433 